\title{
The Economic Strength in Minangkabau Oral Literature
}

\author{
Khairil Anwar \\ Literature Postgraduate Program / Minangkabau Literature Department \\ Faculty of Humanities \\ Andalas University \\ khan_msi@yahoo.co.id; khairrilanwar@gmail.com
}

\begin{abstract}
This paper discusses economic power in Minangkabau oral literature. The case is the oral literature bagurau. Oral literature consists not only of text, but also of context. The text and context contain economic power, which drives the oral literature and wheels of the collective economy of its audiences. The research method used is qualitative. This study observes some of the oral literary utterances of the bagurau that the audience perceives. The narrative is held at night in different places in the Minangkabau cultural area in West Sumatra Province. This analysis uses the theory of structural functionalism. This study finds that in the context of oral literature narrative bagurau always happen money circulation. The money, acting as participation in the creation of oral literary texts and direct transactions between people and people collectively. The money affects the economy of society at large, both in the context of direct and beyond the narrative of oral literature. In every narrative of oral literature there is a large circulation of money and is economically beneficial to the sustainability of oral literature and Minangkabau culture.
\end{abstract}

Keywords - oral literature, money, economic strenght, culture.

\section{INTRODUCTION}

So far the literary critics have been lulled into thinking that works only for works and works contain noble values. Such literary criticism has lasted a long time. Writings about literature always revolve around elements, meanings, and values that are not explained easily in the text.

If historically reviewed, literary works are not merely written texts that are simply in the hands of the reader. Originally, literary works were oral, word-to-ear, from one generation to another (Hutomo, 1991: 1). The oral literature is shared by the public. Even who has the ability to tell it, there will be no complaints of ownership by any particular individual. While this work is present in society involves speakers, realities, texts, and audiences. According to critics, so far the four elements simultaneously support the existence of oral literature.

Historical journeys continued, literary works began written in bark, papyrus, and paper. Spontaneous, formulaik, and fluid literary works are now present as the same work from time to time. Works read by previous and old generations today can also be read by the younger generation. It makes no difference to the work from time to time, unless the paper becomes dull and yellow, the bark and the lontard are antiques. If valued with antiques money becomes high value. When criticism of the work, there is also a writing about the elements, meanings, and noble values contained in the work.

As if literary critics missed. Unwittingly, neither oral literature nor literary writing will exist without the influence of economic factors. The existence of literary works is inevitably have to recognize the role of money. Aesthetics appear, literary works are present in the audience, and in the reader's hands are all influenced by economic power (see Escarpit, 2005). The narrative of oral literature in front of audiences is not just there, nor is literature written in the hands of the reader. The work comes through a series of processes that rely on economic principles. Speakers and writers present works because of the reward motivation of their creative process, money or other forms of appreciation. Of course, behind that there is the role of tradition or culture of the umbrella audience. This is what will be examined in this paper, namely how the economic power in oral literature?

\section{METHOD}

This discussion is not a general phenomenon in literary works, but specialized in oral literature, particularly in the Minangkabau oral literature. This study uses qualitative methods, with the technique participan observer. The paradigm of the approach used is the sociology of literature with the theory of structural functionalism. The oral literature was observed and recorded directly during the narrative. As a sample is the oral literature of bagurau in the Minangkabau cultural area within the administrative area of West Sumatra Province, Indonesia. 


\section{FINDING AND DISCUSSION}

Minangkabau oral literature is scattered in the administrative area of West Sumatra Province. Culturally oral Minangkabau literature also developed Minangkabau rantau area which includes parts of Riau Province, Bengkulu, Jambi, and Negri Sembilan The Country of Malaysia. There are many Minangkabau oral literature that live in West Sumatra. Based on the genre can be grouped as follows. The genres of poetry include: bagurau, salawat dulang, gamad, indang, baadok, batombe, barombai, batintin, baronggeng, and baogueng; Prose genre include barabab, bakobar, bataram, basijobang, basimalin, kudo rantak, and ratok bagindo suman. Drama genres such as randai and tupai janjang (Amir, 2006).

The existence of Minangkabau oral literature is supported by five main aspects, namely speakers, social realities, texts, audiences, and money. According to Escarpit (2005), a person becomes a speaker or author only in relation to someone or in the eyes of others. This implies the existence of a series of activities or institutions that exist between the minds of people who speak with audiences who enjoy. This foundation that makes the idea that the production, distribution, and consumption of literature is a special subject of discussion in this paper, which has so far not gained a place in the minds and writings of critics who are fond of the sociological approach of literature. His discussion was primarily how literature should function in society. Supposedly, literature is seen as a cultural activity generated as part of modern service or industrial activities (Ratna, 2013: 275).

According to Malinowski, in his writings The Functional Theory Of Culture, the elements contained in culture, such as oral literature, intend to meet the series of needs of human instincts associated with his life. The culture is used by humans to adapt to the environment to meet their needs (Sumardjan, 1964; Koentjaraningrat, 1987:160).

Cultural elements have interrelated functions. If one element does not work, the cultural element will die. When it works, so long as that culture will remain alive and sustainable. In general, culture must function and be capable of meeting three levels of human needs, namely biological needs (such as food and family), instrumental (such as law and education), and integrative (such as art and religion) (Pelly 1994: 59; Haviland $1995: 344$ ).

Minangkabau oral literature is still alive because it still works for Minangkabau oral literature is still alive because it still works for the supporting community. In addition, there is also an oral literature that has become extinct and is facing the process of extinction (Anwar, 2010). This phenomenon is a natural phenomenon of culture. That, in relation to the ability of aspects of culture that fulfills its role in public life.

Minangkabau oral literature is still alive because it is still functioning for literature The narrative of Minangkabau oral literature is not merely a mere cultural activity. Although categorized as traditional literature, since the beginning of the narrative activity has offered entertainment services that challenge the reward. At first the narrative was strongly wrapped by the social nature, just removing the dry esophagus bajale baaleh tread. Currently there has been a bargain, there is demand and supply. Speakers with expertise have bargaining power by setting a tariff for their entertainment services. Conversely, the audience bid in accordance with the financial capabilities it has. Thus, being a speaker is a profession or a job in fulfilling the necessities of life, ie paid under a price agreement.

For example, an oral literary speaker bagurau consisting of five people set a tariff of Rp. 1.500.000, - for once nightly report from 20.00 s.d 04.00. Speakers salawat dulang has a tariff of Rp. 2.000.000, - for one group consisting of two people, while for the show required two groups. That is, once the show salawat dulang required a cost of 4,000,000, - for the payer of the speaker. Bagurau tariff is cheaper than salawat dulang. This may be due to the fact that the story of the bagurau is often performed, almost every night. While salawat dulang only shown on the big day of Islam alone.

The above calculations are for speakers only, not including shuttle, consumption, and operational support. Each implementation of the narrative is estimated to cost a minimum of Rp. 500.000, - up to Rp. 1,000,000, - one-time talk.

The money used for a one-time narrative comes from Pagurau Luhak Nan Tigo audience (thus the audience mentions the community). The money is used as a means of participation of 'maisi lapiek' by audiences in the process of narrative. There is no obligation for audiences to participate, such as to enter the arena of having to buy tickets. However, it concerns self-esteem and cultural ideology understood by audiences.

Participation of the audience is shown when actively involved in the process of performing and creating bagelau texts. The text is spontaneous, formulaik, and fluid in every narrative. Even the text is completely different from the previous texts, both the content and the structure. Audiences are instrumental in creating bagelau text. Speakers or bouncers only serve as media and motivator for the birth of the text. Contribution of the audience in the form of demand lyrical song as well as the creation of text wrapped by money maisi lapiek. Every text created and a song request by audiences should be followed by the handover of a sum of money to the tukang oyak, and then the tukang oyak reads the request so the tukang dendang sings it.

The amount of money varies. The number variation is based on the criteria of the created text. The criterion is a new text or an advanced text to translate into a text that will be enjoyed by all the audiences present at the compound. Criteria of the text of the creation of the nature of the text that is being spoken by the tukang dendang, then the money submitted is the amount between Rp. 5,000, - up to Rp. 10.000, -. If the text that was created changed the text that is being spoken of the carpenter then the money submitted amounted to greater between Rp. 20,000.- up to Rp. 50.000, -, even that number is reached Rp. 100.000, - depending on pagurau emotions on the text and the atmosphere of the narrative at the time. As illustrated in the following bagurau text passage. 
40. Tukang Dendang:

"Kilek Marapi jo Buyuang Rimbo,

Kosong Tujueh jo kawan-kawan,

Junjuanglah langik jo bintaro,

Jan sampai bumi kaujanan,

Junjuanglah langik jo bintaro,

Jan sampai bumi kaujanan,

Da Man Kabuik jo Supir Gumarang,

Lai bapanjang lagu iko,

Kalaulah sayang tak saimbang,

Lah sansai surang badan iko

Kalaulah sayang tak saimbang ndeh $d a$,

Lah sansai surang badan iko."

41 Tukang Oyak:

“ 'Sanabu lai lah Pik!' dari Urang Jolong Gadang jo Talang Sarumpun Sulik Aia sapulueh ribu, jo lagu Buru Babi nan dikandakan Pak Camaik Sapuluah Koto limo pulue ribu.' Sudah tu tambah pulo ciek lai, sudah tu tambah pulo sapulueh ribu lai Pik, dari pagurau rombongan Gaduik Bukiktinggi, Malano Tigo Pakaro jo kawan-kawan bana, sapulueh ribu rupiah, 'baulang pantun Pik, salamaik bagurau samalam suntuak, di galanggang Karang Taruna Harapan Saiyo, grup Balam jo Rantiang, Jorong Koto Subarang Nagari Panyalaian, dek siriah lah kami kunyah, pinang alah kami gatok, dek maraso bagurau badunsanak,' dari Bukiktinggi baliau datang, salamaik datang ka dunsanak hadirin hadirat nan hadir samalam kini, tarimo kasih." (Anwar, 2010:207)

\section{Tukang Dendang:}

"Kilek Marapi and Buyuang Rimbo,

Kosong Tujueh and friends,

Stretch the sky and the sky,

Do not let the earth rain,

Spread the heavens and the sky,

Do not let the earth rain,

Da Man Kabuik and Supir Gumarang,

Request extended this song,

If dear unbalanced,

This body is miserable on its own,

Even if unbalanced ndeh Da,

This body is suffering itself. "

\section{Tukang Oyak:}

"'Once again Pik!' From Urang Jolong Gadang and Talang Sarumpun Sulik Aia ten thousand. Song Buru Babi is requested by the Pak Camat of Sapuluah Koto fifty thousand. After that, plus one more, plus it also added ten thousand more Pik, from Gaduik Bukiktinggi Pagurau Group, Malano Tigo Pakaro and friends, ten thousand rupiah, 'repeated poet yo Pik, joking all night long, in the arena of Karang Taruna Harapan Saiyo, Group Balam jo Rantiang, Jorong Koto Subarang Nagari Panyalaian, because of this joking friendship, we have chewed betel, areca we have eaten, 'from Bukiktinggi he came, welcome we say to you presenters present tonight, thank you. "

In the above quoted quotes are seen the carpenter singing Parasaian song. At the same time, some groups of pagurau send a message to the tukang oyak. The message involves a songwriter repeating the song in (requested by Urang Jolong Gadang, Talang Sarumpun, and Malano Tigo Pakaro) requests and some requesting to exchange with the new song (requested by Pak Sapulueh Koto). The demand messages were followed by the handover of some money to the tukang oyak. To repeat the song the money amounted to Rp. 10.000, - while to request a new song the amount of money Rp. 50.000, -. This is the form of circulation and the power of money in the oral literary text of the bagurau which serves to fulfill the aesthetic and social desires of audiences. 
In addition to maisi lapiek, there are other costs that must be expended pagurau audiences to be able to participate in every narrative of oral literature bagurau. The cost is the cost of transportation and consumption for personal and social such as cigarettes and coffee drinks. This bagurau audiences not only come from the collective society around the location of narrative. However, coming from other villages and neighboring districts that are quite far away. Audiences from outside the nagari of the narrative location are the main actors of narrative from beginning to end. While the audience at the location of the narrative only acts as pengramai and mere entertainment lovers. If the bagurau story takes place in Bukittinggi, then the audience may come from neighboring towns and districts, such as Padang Panjang City, Batusangkar, Lubuk Basung, Padang, and Payakumbuh or surrounding areas. Some even come from cities in Riau Province, such as Bangkinang and Pekanbaru.

It shows that to participate in the narration of bagurau audience requires a considerable cost. Money and expenses incurred by these audiences are a form of self-esteem as a community of pagurau. In addition, as a form of understanding of Adat Minangkabau philosophy, namely saiyo sakato sailie samudiek "agreed and cooperation". There is an oral agreement that they must respect and obey unconsciously as part of the pagurau community. The deal is a must to come anywhere where the narrative takes place - because the organizers of the narrative are the people who are part of the community. If there are community members who are often absent they will be subject to social sanctions, such as a boycott of the narrative. In other words, participation in the bagurau narrative is an aesthetic arisan.

In terms of philosophical, pagurau audiences are supporters and perpetrators of Minangkabau culture. They unconsciously apply the philosophy of the sailie samudiek "cooperation" and seiya sekata"agreed", both in the context of narrative and in daily activities. Such a philosophy concerns self-esteem, both individually and socially (Navis, 1986: 56). Every individual is required to jointly participate in every social activity. If there are individuals who do not care then they are considered poor. It will drop his pride, even the dignity of his people or tribe.

The Minangkabau people like to contribute undeniably. From the beginning they have been shaped into socially concerned individuals, who are required to raise their collective, namely, his people, not himself (Naim, 1979: 25). The donation concerns self-esteem. Especially with the activities in the public space, such as the narrative of oral literature. At that time everyone will mangambang leipek kain "wear the best clothes". That is, to come to the arena of narrative people will wear his best clothes. Usually the best clothes are folded in the wardrobe and worn only to attend traditional ceremonies and crowd events.

In this regard, if a person is not present at the event the crowd is considered a poor person. In the philosophy of the sailie samudiek, what the poor say is a person who does not want to go publicly in social activities, not people who do not have the wealth and money to participate, do not have good clothes. This understanding implies that in social interactions rich and poor property is not an indication, but is wealth and social poverty.

In addition, around the arena of narrative also took place trade transactions. The process of buying and selling between audiences with merchants impromptu. The trader supplies the needs of audiences while following the oral literary narrative. How many and how much is not recorded. But the activity of narrative has become an arena for traders to sell, sell the needs of the time. Thus there are three forms of economic activity in the oral literary narrative of bagurau, namely the demand and supply between the responder and the speaker, audience participation in the creation of text, and the sale and purchase between the merchant and the audience.

Bagurau's telling activities are carried out almost every night at different locations in Luhak Nan Tigo Minangkabau. If the average of each night (minus the month of fasting) is estimated money supply of Rp. 5,000,000, -, then one year the money in circulation is approximately Rp. 1.675 million, -. The amount is a huge amount to preserve oral literature. The amount is also a contribution to preserve one aspect of Minangkabau culture. In addition, the money raised after deducting all expenses and reserves for the next event, then the excess is used for the construction of public facilities in place of oral literature is spoken.

Behind all that, the pagurau that became audiences bagurau during the day to do his activities as a professional. They work in various jobs. Attendance in the arena at night makes them a hard worker during the day to earn money. Part of the income from work is used to participate in the oral literary narrative.

Such economic power is the driving force for the existence of oral literature. Therefore, it is necessary to look for the economic phenomenon in the oral literary narrative. The amount of funding of 1.6 billion in a year circulated in the oral literary narrative of bagurau is not a small amount of money. The problem is now how to utilize the potential of oral literature as a conservation agent of Minangkabau culture in the framework of sustainable development.

Therefore, oral literature should not be an object but as a subject of development. In traditional societies it is already under way, but in the view of policy actors, it is reversed. The origin of the project runs no matter whether it will build or otherwise shut down. Often policies are created creating mentally beggars 'mentally proposals'. For reasons of administrative accountability the artist is asked to make a proposal of funding assistance coaching, making reports, and so forth. Finally, creating dependence on government funds among artists to create creativity. It is the wrong policy. Yet in the end there is also awareness of policy makers, how to grow self-reliance among traditional artists.

It is undeniable that the economic element in oral literary activity becomes the driving force. Art for art is just a hypocrisy that makes the perpetrators 'destitute' who often pitied the other side. More radical, the culprit dressed up, looking unkempt, making people look embarrassed. This understanding applies to the artist who tends to tend to modern, not so in the traditional artists. 
The narrative of oral literature in Minangkabau for example, art is not for art, but art for life, art for ritual, art for social, and art for culture. Narrative is done to fulfill the intention of human being of entertainment. Religious rituals also in the series of activities utilize the oral literary narrative. The narrative of oral literature is also a means and social control for the people. And no less important, oral literature is also a medium of socialization of cultural values and forwarding to the next generation. Thus the oral literature becomes living, developing, and functional for human life.

Based on that also, it can be seen that the oral literature in Minangkabau is currently following the dynamics of its society. If listened to the development has a lot of extinct oral literature and not appreciated again by the audience. This is because the oral literature is no longer compatible with the mindset and way of life of the people. Oral literature that is unable to fulfill the present audience will be lost from the realm of culture. While oral literature that exists today is an oral literature that is able to accommodate the taste of the present audience.

The narrative of the Minangkabau oral literature is not to be enjoyed alone by the speakers, but rather to feed the spiritual audience. Oral literature contributes to childbirth and enlivens social solidarity. Furthermore, oral literature becomes one of the cultural preservers. Therefore, with his expertise of spoken oral literature, the speakers are reasonably rewarded and rewarded from the oral literary audiences and supporters of Minangkabau culture.

\section{CONCLUSION AND RECOMMENDATION}

From the above analysis it can be concluded that in the oral literary narrative there is economic power (economic law). That power becomes the motor of oral literature. Any aesthetic participation of audiences in oral literary texts should surrender some money. The power is at once drives the economy of speakers, audiences, and people in the environment of narrative. Beyond the context of oral literature, audiences become tenacious workers to earn money, partly used to participate in the oral literary narrative. In addition, the economic power creates social forces of empathy and social awareness

There is no mention of oral literature apart from economic elements. Without it the oral literature will die. The element makes the dynamic oral literature moves in accordance with the dynamics and tastes of the contemporary community. Therefore, the production, distribution, and consumption of texts are important in oral literature.

Oral literacy activities are able to collect and utilize money of approximately 1.6 billion per year. He has independence. In fact, capable of becoming a social capital for society and the preservation of its culture. Therefore, in the process of oral literary development should be subject not object. Oral literature is empowered as a development agent. Thus there is sustainable cultural development.

\section{References}

Amir, A. et al. (2006). Pemetaan Sastra Lisan Minangkabau. Padang: Unand Press.

Anwar, K. (2010). "Bagurau: Sastra Lisan Minangkabau di Luhak Nan Tigo Sumatera Barat". Disertasi pada Pascasarjana Universitas Udayana Denpasar.

Escarpit, R. (2005). Sosiologi Sastra. Jakarta: Yayasan Obor Indonesia.

Haviland, W A. (1995). Antropologi. Terj. RG. Soekadijo. Edisi 4 Jilid 1. Jakarta: Erlangga.

Koentjaraningrat. (1987). Sejarah Teori Antropologi I. Jakarta: UIPress.

Naim, M. (1979). Merantau: Pola Migrasi Orang Minangkabau. Yogyakarta: Gajahmada University Press.

Nasroen, M. (1957). Falsafah Alam Minangkabau. Jakarta: Bharata.

Navis, A.A. (1986). Alam Terkembang Jadi Guru. Jakarta: Grafitipers.

Pelly, U. (1994). Teori-Teori Sosial Budaya. Jakarta: Dirjen Dikti Dikbud.

Ratna, N K. (2004). Teori, Metode, dan Teknik Penelitian Sastra. Yogyakarta: Pustaka Pelajar.

Sumardjan, S. (1964). Setangkai Bunga Sosiologi. Jakarta: FEUI.

Sudikan, S Y. (2001). Metode Penelitian Sastra Lisan. Surabaya: Citra Wacana. 